\title{
SISTEM PENGARSIPAN DOKUMEN AKREDITASI BERBASIS WEB
}

\author{
Aniek Suryanti Kusuma ${ }^{1)}$ Komang Sri Aryati $^{2)}$ \\ Program Studi Teknik Informatika ${ }^{1)}$ 2) \\ STMIK STIKOM Indonesia, Bali ${ }^{1) 2}$ \\ anieksuryanti@stiki-indonesia.ac.id ${ }^{1)}$ komangsriaryati@gmail.com ${ }^{2)}$
}

\begin{abstract}
A college must be accredited which the accreditation form (Borang) is used as a reference in the quality and feasibility assessment of a study program that conducted by the National Accreditation Board of Higher Education (BAN PT). The college will build a team which consist of some divisions that have their responsibilties for composing the documents based on the accreditation standard. Unfortunatelly, the team faces some problems in composing process. The main problem is the delay in collecting documents that make the team leader could not recapilutating documents. The other problem is the team leader unable to monitor the accreditation progress since there is no monitoring system. This research make a system for managing documents, so the team leader could monitor easier the completeness of document. This application would be developed using HTML, CSS, Javascript, and PHP programming languages. This archive system will store all documents in one place that could be accessed from anywhere. In addition, this system has a facility to communicate between divisions. The system testing using black box testing method to ensure all functions running properly. From the results of this research, it could be concluded this document archive system can monitor the document collection process that make accreditation process run smoothly.
\end{abstract}

Keywords : Document, Accreditation, Archive System

\begin{abstract}
ABSTRAK
Sebuah perguruan tinggi harus terakreditasi dimana Borang digunakan sebagai referensi dalam proses penilaian kualitas dan kelayakan dari sebuah program studi yang dilakukan oleh Badan Akreditasi Nasional Pendidikan Tinggi ( BAN PT ). Perguruan tinggi akan membentuk sebuah tim khusus, yang terdiri dari beberapa divisi yang memiliki tanggung jawab masing-masing dalam penyusunan buku Borang berdasarkan standar yang sudah di tentukan. Tetapi dalam proses penyusunan, tim mengalami beberapa kendala. Kendala utamanya adalah keterlambatan pengumpulan dokumen sehingga kepala tim mengalami masalah dalam proses perekapan dokumen. Selain itu, kepala tim tidak dapat memantau perkembangan persiapan akreditasi dari masing-masing divisi karena tidak ada sistem pengelolaan dokumen.Penelitian ini akan membuat sebuah sistem pengelolaan dokumen-dokumen Borang sehingga mempermudah kepala tim untuk memantau kelengkapan dokumen. Pembangunan aplikasi ini menggunakan bahasa pemrograman HTML, CSS, Javascript dan PHP. Sistem pengarsipan ini akan menyimpan semua dokumen dalam satu wardah yang dapat diakses dari manapun. Selain itu, terdapat fasilitas untuk dapat berkomunikasi antar divisi.Pengujian sistem menggunakan metode black box testing bertujuan untuk memastikan bahwa sistem yang telah dibuat dapat berjalan dengan baik atau tidak. Dari hasil penelitian ini dapat disimpulkan bahwa sistem pengarsipan dokumen akreditasi dapat membantu proses pengumpulan berkas sehingga proses akreditasi dapat berjalan dengan lancar.
\end{abstract}

Kata kunci : Dokumen, Akreditasi, Sistem Pengarsipan 


\section{PENDAHULUAN}

Akreditasi merupakan suatu bentuk pengakuan pemerintah terhadap suatu lembaga pendidikan yang berdasarkan Undang-Undang nomor 22 tahun 1961 yang diberikan oleh Dinas-Dinas Pendidikan dan Kebudayaan berupa tiga tingkatan status yaitu terdaftar, diakui, dan disamakan. Akreditasi dibagi menjadi dua yaitu akreditasi institusi dan akreditasi program studi. Akreditasi program studi merupakan akreditasi terhadap program studi yang dimiliki pada masing-masing institusi perguruan tinggi. Sedangkan akreditasi institusi perguruan tinggi adalah proses penilaian terhadap institusi secara keseluruhan untuk mengetahui komitmen institusi terhadap kapasitas institusi dan efektivitas pendidikan, yang didasarkan pada standar akreditasi yang telah ditetapkan. Akreditasi dilakukan oleh Badan Akreditasi Nasional Perguruan Tinggi (BAN-PT) terhadap semua perguruan tinggi di Indonesia. Evaluasi terhadap mutu kinerja institusi perguruan tinggi dilakukan melalui asesmen terhadap borang akreditasi dan laporan evaluasi diri institusi perguruan tinggi oleh tim asesor yang terdiri atas berbagai keahlian terkait yang berpengalaman dan memahami hakikat penyelenggaraan perguruan tinggi, baik dalam bidang akademik maupun bidang manajemen.

Dalam sebuah kampus proses akreditasi menjadi hal yang sangat penting, sehingga dalam persiapan akreditasi tersebut pihak kampus akan membentuk sebuah tim penyusun Buku Borang. Ketua tim penyusun Buku Borang yang memegang tanggung jawab dalam penyusunan standar-standar yang sudah ditentukan. Borang adalah sebuah buku yang berisi segala informasi terkait perguruan tinggi. Buku borang terdiri dari 7 standar yaitu standar 1 visi misi, sasaran dan tujuan dari program studi atau institusi, standar 2 yaitu mengenai tata pamong dan penjaminan mutu, standar 3 mengenai mahasiswa dan kelulusan, standar 4 mengenai sumber daya manusia yaitu tenaga pendidik atau kependidikan, standar 5 mengenai kurikulum, standar 6 mengenai sarana prasarana dan keuangan dan standar 7 mengenai penelitian dan pengabdian masyarakat. Masing-masing standar tersebut membutuhkan bukti-bukti dokumen baik tercetak maupun tidak tercetak. Seluruh kelengkapan dokumen borang dari masingmasing standar tersebut dikirim ke Badan Akreditasi Nasional Perguruan Tinggi (BANPT).
Adapun kendala yang dihadapi oleh ketua tim selama adalah ketika dokumen yang harusnya dikumpulkan oleh masing-masing anggota tim penyusunan borang mengalami keterlambatan pengumpulan sehinggan mengakibatkan ketua tim tidak memiliki banyak waktu untuk merekap dokumendokumen tersebut. Proses yang berjalan saat ini adalah ketua tim harus mendatangi tiap-tiap lembaga dan unit untuk diingatkan agar segera mengumpulan dokumen-dokumen tersebut. Kesulitan ketua tim mendapatkan dokumendokumen secara tepat waktu, dikarenakan kepala-kepala lembaga maupun unit yang bertanggung jawab atas dokumen yang harus dikumpulkan sebagai dokumen terlaporkan pada boring, sangat sulit dijumpai dan dikumpulkan karena merangkap sebagai dosen. Dokumen yang sudah selesai terkadang tim bingung meletakkan sehingga saat dibutuhkan harus membuka tumpukan file lagi. Oleh karena itu penulis mengusulkan sebuah solusi yang dapat mengatasi masalah tersebut dengan membuat sebuah sistem yang dapat membantu proses pengumpulan dokumen-dokumen tersebut dimana proses pengumpulan dokumen tersebut akan dikelompokkan berdasarkan standarnya masing-masing. Dokumen yang telah selesai dibuat dapat langsung diunggah dan dokumen yang akan digunakan dapat diunduh oleh masing-masing tim yang berkepentingan. Pada sistem ini juga masing-masing tim dapat bekomunikasi dan memberikan komentar terhadap dokumen yang telah dibuat. Dari uraian permasalahan di atas, dipandang perlu untuk membuat sebuah sistem dengan judul "sistem pengarsipan dokumen akreditasi berbasis web".

\section{TINJAUAN PUSTAKA}

\section{Sistem}

Beberapa pendapat menurut para ahli yang mendukung tentang pengertian sistem antara lain adalah :

1. Sistem adalah sekelompok dua atau lebih komponen yang saling berkaitan (interrelated) atau sub-sub elemen yang bersatu untuk mencapai tujuan yang sama (common purpose) [1].

2. Sistem adalah suatu kesatuan yang terdiri dari dua atau lebih komponen atau subsistem yang berinteraksi untuk mencapai suatu tujuan. Secara sederhana, suatu sistem dapat diartikan sebagai suatu kumpulan atau himpunan dari unsur, 
komponen atau variabel-variabel yang terorganisir, saling berinteraksi, saling ketergantungan satu sama lainnya dan terpadu [2].

3. Sistem dapat diartikan sebagai serangkaian komponen-komponen yang saling berinteraksi dan bekerja sama untuk mencapai tujuan tertentu [5].

Menurut beberapa para ahli seperti yang dikutip di atas, sistem merupakan suatu kesatuan kerangka kerja yang terstruktur dan saling berkaitan satu sama lain yang memberikan masukan dan menghasilkan keluaran sehingga menghasilkan sebuah informasi untuk mencapai tujuan yang diharapkan.

\section{Sistem Pengarsipan}

Pengarsipan merupakan rangkaian kegiatan dan suatu proses dari mulai penciptaan, penerimaan, pengumpulan, pengaturan, pemeliharaan dan perawatan serta penyimpanan berkas menurut sistem tertentu.yaitu ketika dibutuhkan dapat ditemukan. Dan ketika arsip-arsip tersebut sudah tidak dibutuhkan lagi atau sudah tidak memiliki nilai guna lagi, maka arsip-arsip yang bersangkutan dapat dimusnahkan.

1. Menurut Undang-undang No.7 tahun 1971 tentang ketentuan-ketentuan Pokok kearsipan Bab I pasal 1, arsip adalah: Naskah-naskah yang dibuat dan diterima oleh lembaga Negara dan badan-badan pemerintah dalam bentuk corak apapun baik dalam keadaan tunggal maupun berkelompok dalam rangka pelaksanaan kegiatan Pemerintah. Naskah-naskah yang dibuat dan diterima oleh badan-badan swasta dan atau perorangan, dalam bentuk corak apapun baik dalam keadaan tunggal maupun berkelompok dalam rangka pelaksanaan kehidupan kebangsaan.

2. Kearsipan adalah suatu metode atau cara yang direncanakan dan dipergunakan untuk menyimpan, pemeliharaan arsip bagi individu maupun umum dengan memakai indeks yang sudah ditentukan, biasanya untuk keperluan filling ini dipergunakan lemari, laci cabinet dari bahan baja tahan karat atau dari kayu yang terkunci, jauh dari bahaya yang tidak diinginkan [4].

Adapun beberapa macam teknik pengarsipan baik secara logis ataupun secara sistematis adalah sebagai berikut:

1. Sistem Abjad (Alphabetical Filling System)
Sistem Abjad adalah sistem penyimpanan arsip dengan memakai metode penyusunan menurut abjad. Umumnya dipakai untuk arsip yang dasar penyusunannya dilakukan terhadap nama orang, nama perusahaan / organisasi, nama tempat, nama benda dan subjek masalah.

2. Sistem Perihal (pokok isi dokumen)

Sistem perihal adalah cara penyimpanan dan penemuan kembali dokumen dan berpedoman pada perihal dokumen atau pokok isi dokumen.

3. Sistem Nomor

Sistem ini menetapkan kode dokumen berdasarkan nomor yang ditetapkan untuk dokumen yang bersangkutan.

4. Sistem Geografis / Wilayah

Sistem geografis atau wilayah adalah suatu sistem penyimpanan arsip berdasarkan pembagian wilayah atau daerah yang menjadi alamat suatu surat. Surat disimpan dan diketemukan kembali menurut kelompok atau tempat penyimpanan berdasarkan geografi / wilayah / kota dari surat berasal dan tujuan surat dikirim.

5. Sistem Tanggal (Chronologis)

Sistem tanggal adalah sistem penyimpanan surat yang didasarkan kepada tanggal surat diterima (untuk surat masuk) dan tanggal surat dikirim (untuk surat keluar).

\section{Data Flow Diagram}

DFD adalah suatu model logika data atau proses yang dibuat untuk menggambarkan asal data dan tujuan data yang keluar dari sistem, tempat penyimpanan data, proses apa yang menghasilkan data tersebut serta interaksiantara data yang tersimpan dan proses yang dikenakan pada data tersebut [3].

Didalam DFD sendiri terdapat 3 level atau tingkatan yaitu :

1. Diagram Konteks : menggambarkan satu lingkaran besar yang dapat mewakili seluruh proses yang terdapat di dalam suatu sistem. Merupakan tingkatan tertinggi dalam DFD dan biasanya diberi nomor 0 (nol). Semua entitas eksternal yang ditunjukkan pada diagram konteks berikut aliran-aliran data utama menuju dan dari sistem. Diagram ini sama sekali tidak memuat penyimpanan data dan tampak sederhana untuk diciptakan.

2. Diagram Nol (diagram level-1) : merupakan satu lingkaran besar yang mewakili lingkaran-lingkaran kecil yang ada di dalamnya. Merupakan pemecahan dari diagram Konteks ke diagram Nol. di 
dalam diagram ini memuat penyimpanan data.

3. Diagram Rinci : merupakan diagram yang menguraikan proses apa yang ada dalam diagram Nol.

Tabel 1. Simbol DFD (Data Flow Diagram)

\begin{tabular}{|l|c|l|}
\hline $\begin{array}{c}\text { Gane dan } \\
\text { Sarson }\end{array}$ & $\begin{array}{c}\text { Yourdon } \\
\text { dan } \\
\text { DeMarco }\end{array}$ & \multicolumn{1}{c|}{ Keterangan } \\
\hline$\square$ & $\begin{array}{l}\text { External Entity merupakan entitas di lingkungan luar sistem yang } \\
\text { dapat berupa orang, organisasi atau sistem lain yang berada di } \\
\text { lingkungan luar yang akan memberikan input atau menerima } \\
\text { output dari sistem }\end{array}$ \\
\hline & $\longleftarrow$ & $\begin{array}{l}\text { Arus Data yang menunjukkan arus dari data yang dapat berupa } \\
\text { masukan untuk sistem atau hasil dari proses sistem. }\end{array}$ \\
\hline & $\begin{array}{l}\text { Proses adalah kegiatan atau kerja yang dilakukan oleh orang, } \\
\text { mesin, atau komputer. }\end{array}$ \\
\hline$\square$ & $\begin{array}{l}\text { Simpanan Data merupakan simpanan dari data yang hasilkan dari } \\
\text { proses. }\end{array}$ \\
\hline
\end{tabular}

\section{Pengujian Perangkat Lunak}

Pengujian adalah sebuah proses terhadap aplikasi/program untuk menemukan segala kesalahan dan segala kemungkinan yang akan menimbulkan kesalahan sesuai dengan spesifikasi perangkat lunak yang telah ditentukan sebelum aplikasi tersebut diserahkan kepada pelanggan.

Pengujian merupakan proses eksekusi program yang telah selesai dibuat yang bertujuan untuk menemukan kesalahan. Pengujian yang baik adalah pengujian dengan probabilitas penemuan kesalahan yang tidak diduga, sedangkan pengujian yang sukses adalah pengujian yang berhasil mengatasi penyelesaian penemuan kesalahan yang tidak diduga.

Pengujian yang akan dilakukan pada penelitian ini adalah pengujian Black Box. Pengujian black box berfokus pada persyaratan fungsional perangkat lunak. Pengujian black box berusaha menemukan kesalahan dalam kategori : fungsisungsi yang tidak benar atau hilang, kesalahan interface, kesalahan dalam struktur data atau akses database eksternal, kesalahan kinerja, dan inisialisasi kesalahan terminasi (Pressman, 2002). Adapun pedoman pengujian pada metode black box adalah pengujian Grafical User Interfaces (GUI), pengujian arsitektur client/server, pengujian dokumentasi dan fasilitas help, pengujian sistem real-time.

\section{METODOLOGI PENELITIAN}

Penelitian ini mengikuti prosedur untuk pengembangan sistem (SDLC), yang terdiri dari tahap identifikasi masalah, pengumpulan data dan analisa kebutuhan, perancangan sistem, implementasi rancangan dan pengujian sistem. Metode yang dipakai dalam pengumpulan data adalah wawancara, observasi langsung di lapangan, dan kepustakaan. Analisa kebutuhan yang dilakukan berupa analisa sistem yang telah ada, analisa kebutuhan fungsional sistem, dan kebutuhan non fungsional sistem.

Tahapan selanjutnya adalah proses perancangan sistem, yang diawali dengan pembuatan Contect Diagram (CD), Data Flow Diagram (DFD) dilanjutkan dengan pmbuatan Conceptual Data Model (CDM) dan Physical Data Model (PDM). Sistem yang akan dibangun berbasis web. Setelah sistem berhasil dibuat, pengujian dilakukan dengan menggunakan metode Black Box Testing.

\section{Perancangan Sistem}

Context Diagram yang dapat dilihat pada Gambar 1 digunakan untuk menggambarkan proses perancangan dalam pembuatan Sistem Pengarsipan Dokumen. Dalam contect diagram terdapat 2 external entity yaitu admin dan user yang masuk ke dalam sistem. 


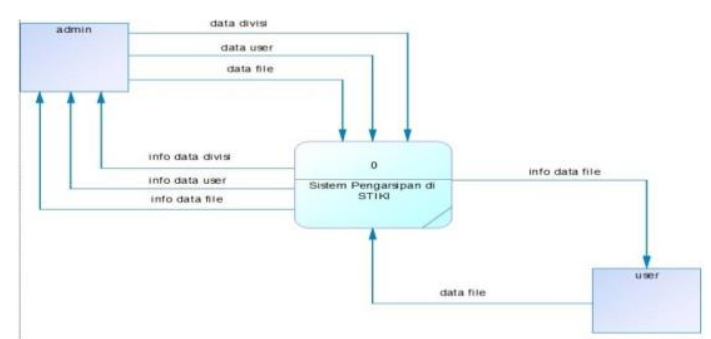

Gambar 1. Context Diagram Sistem Pengarsipan

Data Flow Diagram merupakan penjabaran dari Contect Diagram yang menjelaskan alur proses kerja dari sistem yang akan dibuat dengan lebih terperinci. Terdapat dua entitas yaitu admin dan user dan tiga proses yaitu mengelola data divisi, mengelola data user dan mengelola file. Admin bisa menambah divisi dan user. Sedangkan user dapat mengelola file. Gambaran umum DFD (data flow diagram) pada sistem pengarsipan dokumen dapat dilihat pada gambar 2 .

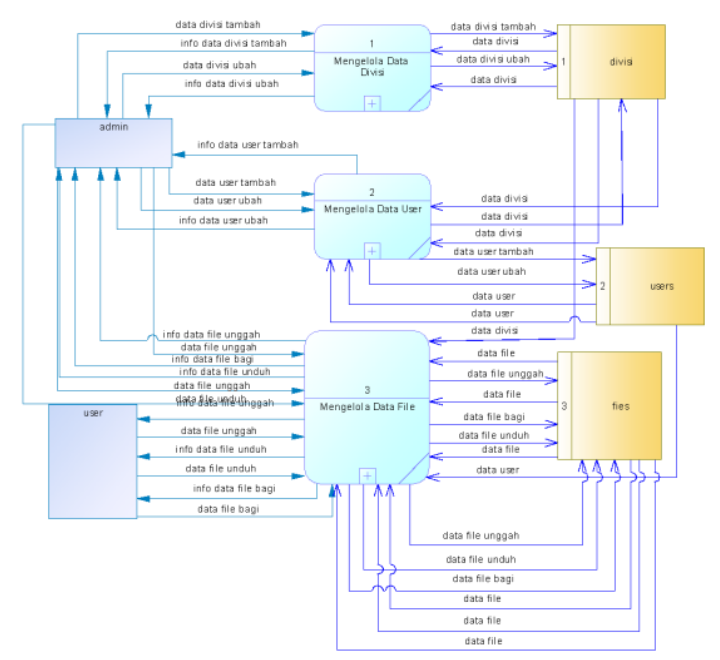

Gambar 2. Data Flow Diagram level 0 Sistem Pengarsipan.
Pada gambar 3 dapat dilihat bentuk physical data model (PDM) yang dhasilkan dari conceptual data model (CDM). PDM bersifat lebih khusus dan detail. Perancangan ini merupakan representasi fisik dari basisdata (database) untuk sistem informasi pengarsipan

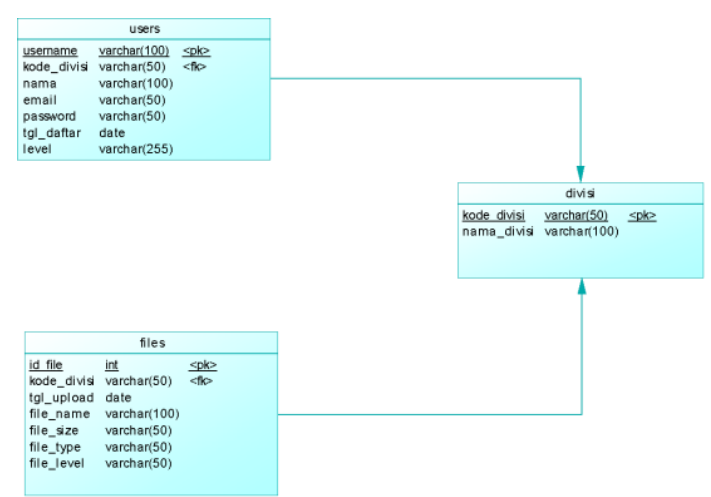

Gambar 3. Physical Data Model (PDM) Sistem Pengarsipan

\section{Rancangan Pengujian Sistem}

Pengujian sistem dimaksudkan untuk memastikan perangkat lunak yang dibuat dapat berjalan sesuai harapan untuk menghasilkan perangkat berkualitas (software quality). Pendekatan black box testing digunakan untuk mengevaluasi kebutuhan fungsional dari kinerja sistem pengarsipan yang telah dibuat. Adapun aspek yang akan diujikan seperti ditunjukkan Tabel 2. 
Tabel 2. Skenario pengujian Sistem

\begin{tabular}{|c|c|c|c|}
\hline No & Fungsi & Skenario Pengujian & Hasil Proses yang diharapkan \\
\hline \multirow[t]{4}{*}{1} & Login & $\begin{array}{l}\text { Username dan password } \\
\text { dikosongkan }\end{array}$ & $\begin{array}{l}\text { Sistem akan menolak akses login dan } \\
\text { menampilkan notifikasi }\end{array}$ \\
\hline & & $\begin{array}{l}\text { Mengisi username tapi } \\
\text { password dikosongkan, atau } \\
\text { sebaliknya }\end{array}$ & $\begin{array}{l}\text { Sistem akan menolak akses login dan } \\
\text { menampilkan notifikasi }\end{array}$ \\
\hline & & $\begin{array}{l}\text { Mengisi username benar dan } \\
\text { password salah atau } \\
\text { sebaliknya }\end{array}$ & $\begin{array}{l}\text { Sistem akan menolak akses login dan } \\
\text { menampilkan notifikasi }\end{array}$ \\
\hline & & $\begin{array}{l}\text { Mengisi username dan } \\
\text { password dengan benar }\end{array}$ & $\begin{array}{l}\text { Sistem menerima akses login dan kemudian } \\
\text { langsung menampilkan halaman utama. }\end{array}$ \\
\hline \multirow[t]{3}{*}{2} & $\begin{array}{l}\text { Menu } \\
\text { Unggah } \\
\text { file }\end{array}$ & Memilih halaman unggah & Muncul halaman unggah file \\
\hline & & Klick Tombol Choose File & Dokumen dapat dipilih \\
\hline & & $\begin{array}{l}\text { Muncul pilihan user yang } \\
\text { akan dibagikan file tersebut } \\
\text { dan muncul pilihan standar }\end{array}$ & $\begin{array}{l}\text { Dapat memilih user yang dapat menggunakan file } \\
\text { dan masuk ke dalam kelompok standar sesuai } \\
\text { dengan pilihan }\end{array}$ \\
\hline \multirow[t]{3}{*}{3} & $\begin{array}{l}\text { Fungsi } \\
\text { unduh } \\
\text { File }\end{array}$ & Memilih file yang diunduh & $\begin{array}{l}\text { File yang akan diunduh terpilih dan tombol unduh } \\
\text { dan kirim aktif. }\end{array}$ \\
\hline & & Klick Tombol unduh & Muncul file yang diunduh \\
\hline & & Klick Tombol kirim & $\begin{array}{l}\text { Muncul pilihan divisi yang akan dibagikan dan } \\
\text { tombol bagi bisa di klick }\end{array}$ \\
\hline
\end{tabular}

\section{MPLEMENTASI}

\section{Halaman Login}

Pada halaman login seperti yang terlihat pada gambar 4 di bawah menampilkan form login yang terdiri dari dua textbox pengisian antara lain username dan password dan satu button login.

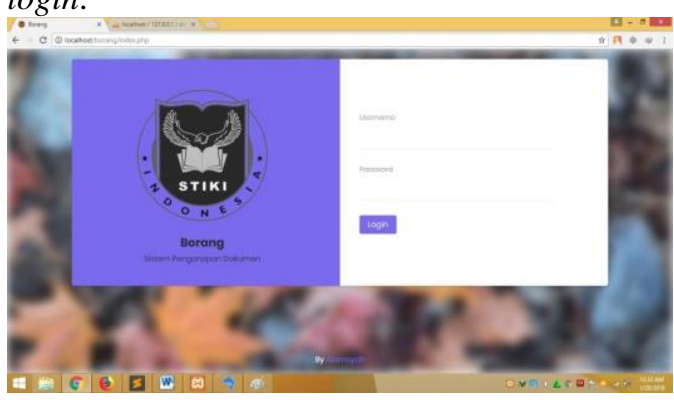

Gambar 4. Halaman Login

Pada halaman Home yang dapat dilihat pada gambar 5 ini menampilkan dokumen-dokumen dari divisi tersebut baik dokumen yang yang telah di unggah maupun dokumen dari divisi lain yang telah dibagikan. Pada halaman home admin akan muncul beberapa kelompok standar sesuai dengan kebutuhan borang. Hal ini bertujuan untuk mempermudah admin mencari file dokumen yang dibutuhkan dan dapat melihat file yang dibagikan. Pada halaman ini memiliki tombol button klik yang berwarna biru pada kolom action berfungsi untuk mengunduh data serta warna hijau untuk mengirim data ke devisi lain

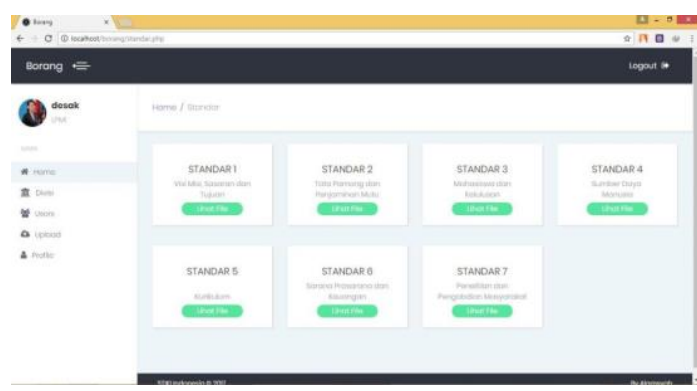

Gambar 5. Halaman Home

Detail dari file dokumen per-standar dari semua divisi yang ada ditampilkan dalam tabel yang terdiri dari beberapa kolom yang menjelaskan file dari divisi mana, nama file dokumen, tanggal di unggahnya dan action yang terdiri dari dua button masing-masing berfungsi untuk mengunduh file (berwarna biru) dan button kirim untuk membagi file tersebut (berwarna hijau) dengan divisi lain seperti yang terlihat pada gambar 6 . 


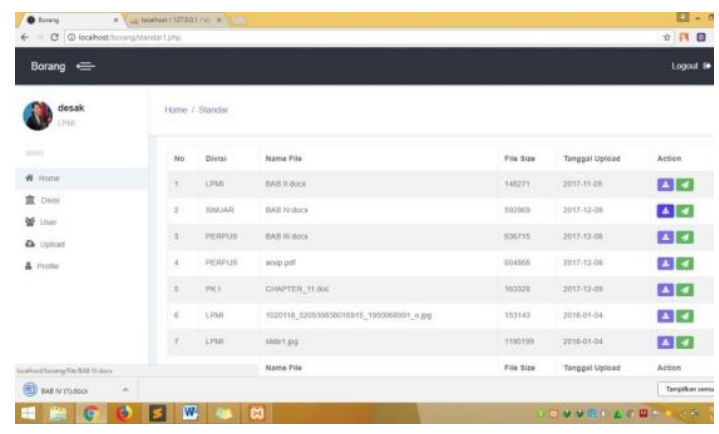

Gambar 6. Halaman Home

Pada gambar 7 dapat dilihat ada beberapa checkbox yang dapat dipilih untuk berbagi file ke divisi lainnya. User dapat memilih dan membagikan file kepada lebih dari satu divisi. Klick button bagi untuk membaginya ke devisi yang dituju

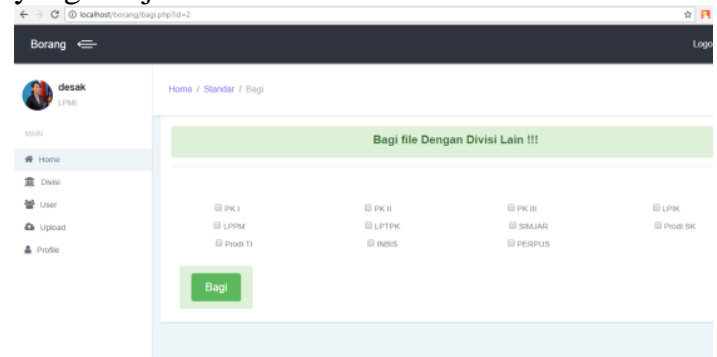

Gambar 7. Halaman Home

\section{HASIL DAN PEMBASAHAN}

Berdasarkan hasil pengujian menggunakan black box testing, maka didapatkan hasil sebagai berikut: Sistem pengarsipan dokumen akreditasi yang dibangun dapat membantu dalam pengelolaan file borang dan dapat membagikan file ke divisi yang membutuhkan Dengan demikian, dapat dinyatakan bahwa semua komponen telah menunjukkan fungsi sesuai dengan perencanaan. Berdasarkan hasil pengujian, semua aspek yang diuji menunjukkan hasil yang valid 


\section{Hasil Pengujian Sistem}

Tabel 3. Hasil Pengujian Sistem

\begin{tabular}{|c|c|c|c|c|}
\hline No & Fungsi & Skenario Pengujian & Hasil Proses yang diharapkan & Hasil Uji \\
\hline \multirow[t]{4}{*}{1} & Login & $\begin{array}{l}\text { Username dan password } \\
\text { dikosongkan }\end{array}$ & $\begin{array}{l}\text { Sistem akan menolak akses login } \\
\text { dan menampilkan notifikasi }\end{array}$ & $\begin{array}{l}\text { Sesuai } \\
\text { Harapan }\end{array}$ \\
\hline & & $\begin{array}{l}\text { Mengisi username tapi } \\
\text { password dikosongkan, atau } \\
\text { sebaliknya }\end{array}$ & $\begin{array}{l}\text { Sistem akan menolak akses login } \\
\text { dan menampilkan notifikasi }\end{array}$ & $\begin{array}{l}\text { Sesuai } \\
\text { Harapan }\end{array}$ \\
\hline & & $\begin{array}{l}\text { Mengisi username benar dan } \\
\text { password salah atau } \\
\text { sebaliknya }\end{array}$ & $\begin{array}{l}\text { Sistem akan menolak akses login } \\
\text { dan menampilkan notifikasi }\end{array}$ & $\begin{array}{l}\text { Sesuai } \\
\text { Harapan }\end{array}$ \\
\hline & & $\begin{array}{l}\text { Mengisi username dan } \\
\text { password dengan benar }\end{array}$ & $\begin{array}{l}\text { Sistem menerima akses login dan } \\
\text { kemudian langsung menampilkan } \\
\text { form aplikasi utama halaman admin. }\end{array}$ & $\begin{array}{l}\text { Sesuai } \\
\text { Harapan }\end{array}$ \\
\hline \multirow[t]{3}{*}{2} & $\begin{array}{l}\text { Menu } \\
\text { Unggah } \\
\text { file }\end{array}$ & Memilih halaman unggah & Muncul halaman unggah file & $\begin{array}{l}\text { Sesuai } \\
\text { Harapan }\end{array}$ \\
\hline & & Klick Tombol Choose File & Dokumen dapat dipilih & $\begin{array}{l}\text { Sesuai } \\
\text { Harapan }\end{array}$ \\
\hline & & $\begin{array}{l}\text { Muncul pilihan user yang } \\
\text { akan dibagikan file tersebut } \\
\text { dan muncul pilihan standar }\end{array}$ & $\begin{array}{l}\text { Dapat memilih user yang dapat } \\
\text { menggunakan file dan masuk ke } \\
\text { dalam kelompok standar sesuai } \\
\text { dengan pilihan }\end{array}$ & $\begin{array}{l}\text { Sesuai } \\
\text { Harapan }\end{array}$ \\
\hline \multirow[t]{3}{*}{3} & $\begin{array}{l}\text { Fungsi } \\
\text { unduh } \\
\text { File }\end{array}$ & Memilih file yang diunduh & $\begin{array}{l}\text { File yang akan diunduh terpilih dan } \\
\text { tombol unduh dan kirim aktif. }\end{array}$ & $\begin{array}{l}\text { Sesuai } \\
\text { Harapan }\end{array}$ \\
\hline & & Klick Tombol unduh & Muncul file yang diunduh & $\begin{array}{l}\text { Sesuai } \\
\text { Harapan }\end{array}$ \\
\hline & & Klick Tombol kirim & $\begin{array}{l}\text { Muncul pilihan divisi yang akan } \\
\text { dibagikan dan tombol bagi bisa di } \\
\text { klick }\end{array}$ & $\begin{array}{l}\text { Sesuai } \\
\text { Harapan }\end{array}$ \\
\hline
\end{tabular}

\section{SIMPULAN}

Berdasarkan pelaksanaan penelitian yang telah dilakukan maka disimpulkan sebagai berikut: Proses penelitian ini dimulai dari pengumpulan data, perancangan sistem dengan menggunakan data Flow Diagram(DFD), pembuatan sistem ini berbasis web, dan diakhiri dengan pengujian sistem dengan menggunakan Black box Testing.
Sistem pengarsipan dokumen akreditasi yang dibangun dapat membantu dalam pengelolaan file borang dan dapat membagikan file ke divisi yang membutuhkan.Dari hasil pengujian dengan menggunakan metode blackbox testing, unjuk kerja dari sistem yang dirancang berjalan dengan baik dan sesuai dengan fungsinya. 


\section{DAFTAR PUSTAKA}

[1] James A, H. 2001. Sistem Informasi

Akuntansi, Third. Jakarta: Salemba

Empat.

[2] Jogiyanto, H. 1999. Analisis dan

Desain Sistem Informasi :

Pendekatan Terstruktur Teori dan

Praktek Aplikasi Bisnis. Yogyakarta:

Andi.

[3] Kusrini, M. 2007. Strategi

Perancangan dan Pengelolaan Basis

Data. Yogyakarta: Andi.

[4] Maulana, M. . 1974. Administrasi

Kearsipan. Jakarta: Bharata.

[5] Soeherman, B., dan Pinontoan, M. 2008. Designning Information System Concepts dan Cases With Visio. Jakarta: PT. Elex Media Komputindo.

[6] Sutanta, E. 2011. Basis Data dalam Tinjauan Konseptual. Yogyakarta: Andi.

[7] Yuhefizar, dan Dkk 2009. Cara Mudah Membangun Website Interaktif Menggunakan Content Management System Joomla Edisi Revisi. Jakarta: PT. Elex Media Komputindo. 